\title{
14
}

Rupantaran : A Multidisciplinary Journal

Vol. V : pp 14-27, September, 2021

ISSN (Print) : 2091-0061, ISSN (Online) : 2738-9960

https://doi.org/10.3126/rupantaran.v5i01.39829

Research Management Cell (RMC)

Dhankuta Multiple Campus, Dhankuta

Tribhuvan University, Nepal

\section{Elderly Care: Policy Initiatives and Older Parents' Perception in Nepali Society}

\author{
Chandra Upadhyay $(\mathrm{Ph} \mathrm{D})^{1}$ \\ Email: upadhyaychandra13@gmail.com
}

\begin{abstract}
Elderly care in the present day Nepali society is affected with the changes in the family arrangements. The old age situations without children, children away from home, and out migration of children create impacts on the maintenance and care of the elderly parents. The major issues of apprehension with the elderly population are their health status including their social, psychological and emotional conditioning, and elderly support activities. Based on focused group discussions and analysis of the selected narratives collected through personal interviews in Province-1, this paper finds, more or less, a common perspective of the elderly parents that their life situations become lonelier and difficult as they become older and feel helpless in absence of their children. Social inclusion and integration of senior citizens have been two major aspects in the state policy interventions while the daily life issues and activities of the elderly are of equal concern. The initiatives for elderly care shall be based on their interest, choices and needs.
\end{abstract}

Keywords: old age care, migration, social security, policy initiatives, Province-1

\section{Introduction}

This paper is an effort to comprehend the perceptions on the situation of the elderly* parents when they are living without their children. The ongoing demographic transition demands priority shifts in national policies and programs (Geriatric Center Nepal-GCN, 2010) and there are several social and legal backdrops on elderly care at the family and state level. Elderly care in any society is affected with the rise in the size of population ageing as a result of increasing longevity and falling fertility even in the highly populous countries (Agrawal et al., 2020). The national census

1. Dr. Upadhyaya is an asst. Professor of Sociology at Tribhuvan University Mahendra Morang Adarsha Multiple Campus, Biratnagar. 
statistics in Nepal showed that in 2011, Nepal had 2.1 million elderly inhabitants which made $8.1 \%$ of the total population in the country. Shrestha (2012) observed that the proportion of the older population was growing world-wide with the combined effects in lowering the fertility rates, and improved health services and longevity. Shrestha further argued that the elderly people in Nepal were facing several health problems and the government initiatives were slow. The desire to "postpone death at almost any cost' remained a prime motive of the modern social organizations. Ossewaarde (2014). This is a positive indication for a higher life expectancy but with subsequent challenges on the maintenance and care of the elderly population. Yet, very few researches are found about the situation of care to maintain the quality of life of the elderly population after the children migrate leaving behind their elderly parents and the senior members in the family.

Several social science studies on ageing entail substantial sociological discourse and policy implications in Nepal. The issues of senior citizens are studied taking into consideration the local context, national policy framework and international recommendations. However, as Ossewaarde (2014) commented that the 'aged society' demarcated by population ageing affects all the social structure including the families and constitutes several challenges especially when coupled with capitalism, globalization and migration of their family members. Sebastian and Symala (2018) found that the elderly population living with their children was empowered with dignity and care; that they achieved over their life, while those living without children or living alone were less likely to get dignity and care. Similarly, there are researchers who studied the situation and care of the elderly maintaining the quality of life of the aged population. Joshi (2019) worked on the elderly people's perceptions in the rural setting of Kailali district in western Nepal towards their Quality of Life (QoL) and rated good or bad on the basis of their standards, their hopes, pleasure and concerns. In the study with 547 sampled respondents, $85.15 \%$ of the elderly people living with their sons and daughter-in-laws, and $2.74 \%$ living alone, the researcher calculated his results that $35.4 \%$ of the first category of respondents living with their sons and daughter-in-laws scored good QoL while $47.7 \%$ respondents living alone had poor quality of their lives. Thus, elderly care is an important aspect of family life in Nepali society.

The standard in the Nepali social and cultural setting is that family support to elderly parents is important. The children and primarily sons are obliged caretakers of the elderly parents, and any discrepancy to this practice is not perceived as normal. Family life is equally important in adding qualitative significance and dignity for the elderly parents (Joshi, 2019). However, the seclusion of the left behind parents has become a major concern of maintenance, health and psycho-social wellbeing in 
contemporary Nepali society. Social inclusion and integration of the senior citizens are found as two major aspects in the national policy interventions (the constitution of Nepal 2015, Senior Citizen^ Act 2007, 15th National Plan, 2019/20-2023/24) while their daily life issues and activities remain as key concerns. This research is an assessment of the socio-psychological impact of physical absence of offspring due to childlessness, being away from home or outmigration of the children on the left behind elderly parents.

The researcher here makes an effort to explain the perspective on the status of care of the elderly parents. The issues of the lonely and / or left behind senior citizens are studied in the national context in general and specific to province no 1 of federal Nepal considering the social and cultural conditions at their home (family) and policy backdrops at the state level. Two research questions have been used in the study: how the elderly parents narrate the company and care from their children and family, and what practical expectations the elderly parents keep from their children and the society at large. The main objectives of the research are to assess the impact of physical absence of the offspring on the left behind elderly parents, and to examine the status of care of the elderly population considering their social and psychological perceptions at the family level and within the social and policy backdrops at state level.

\section{Methods and Materials}

This cross-sectional research on analyzing the information, from more or less the same age category samples to examine their viewpoint is empirically carried out in Province no. 1 of Nepal to understand the perception of the left behind elderly parents in their life situations after their children have migrated or are away from home. The research largely uses qualitative information supported by quantitative document evidence. The qualitative analysis and interpretation are drawn from the primary data recorded through case studies, in-depth interviews using checklist and interview guidelines. The respondents selected are the elderly parents and their family members, where available, and other stakeholders including the neighbours of the migrants' family and the officials at the government and non-governmental agencies in the study area. In-depth interviews are conducted to understand the underlying perceptions of the elderly for their self- narrated stories. The elderly respondents are interviewed at the day care centers. Focused Group Discussions (FGDs) were conducted with the senior citizens at 2 day care centers, (in practice day clubs) the 'Paropakar Diwa Sewa Kendra' and Bishnumaya Diwa Sewa Kendra 'in Biratnagar. Both of these day care centers are managed by the local community organizations with the support of Biratnagar Metropolitan City in Province-1.The narratives of the selected respondents 
helped to explore various aspects of the senior lives. However, the designed primary data collection plan for this research was greatly affected by COVID-19 pandemic.

Selected virtual discussions on the issues of senior citizens and online interview videos and documentaries created by medical professionals have been used to understand the family wellbeing and health issues of the elderly citizens. For documented evidence, the Constitution of Nepal 2015, Senior Citizen Act 2006, Senior Citizen Rule 2065, the $15^{\text {th }}$ national plan and the $1^{\text {st }}$ Periodic Plan(2019/202024/25)of Province-1, policies of the MoWCSC, the areas for senior citizens in Sustainable Development Goals (SDGs), and the international conventions to which Nepal is a party are briefly assessed for this study. The government in Province no.1 was found working on establishment and management of a 'Senior Citizen Village' (JesthaNagarikSewa Ashram/Gram), for which a study team was formed and a report based on the findings from all the 14 districts in the province had already been submitted to the Ministry of Social Development (MoSD). This document worked for understanding the status of the senior citizens in the province. This researcher's access to the policy documents, communications with the designated officials, and contacts with the representatives of various non-governmental organizations working on the rights and issues of the aged population while working as an expert in the team of framing policy on senior citizens in Province No.1 have largely supported in making the policy reviews and gathering primary experiences of the elderly population in the province.

\section{Results and Discussion}

Absence of children has several impacts on the maintenance and care of the elderly parents. The basic concerns evenly associated with the status of the aged population are their health conditions, their social and psychological status, their family support activities in enjoying a life with personal interest and freedom. The care and maintenance of the elderly people entail substantial scholarly discourse and policy implications in current Nepali society. The discussion of the present research emphasizes on some issues including migration and family life, a brief review of policies on senior citizens in Nepal and the basic social and psychological variables to be maintained as of concern for the elderly population.

International migration and labour mobility is intent for a better life of the migrant and the dependent family. Employment is a driver of foreign migration in province number 1 and in Nepal in general. The most tangible and least controversial consequences such as remittance, education and health care are taken as significant pull factors analyzing foreign migration of Nepali populace (Upadhyay2020). The tangible impact is the remittance from their migrated children but there are large 
numbers of intangible socio-cultural consequences on the left behind senior citizens. The most significant are the management and care of the elderly with their rights to live a dignified life in their 'autumn years'. This is also an important aspect of the government policy discourse. Migration, in its various forms, is a complex human process of permanent change of residence which is in practice for ages. The causes and perpetuations of migration are equally important. Migration not only creates constraints in the rural labour force but also there are several socio-economic consequences of migration. On one hand, search of livelihood and better standard of living are commonly understood motives of migration, and on the other, there are socio-economic status issues between the remittances receiving households and remittances non-receiving households.

Policies on senior citizens in Nepal with reference to Province No.1 are of interest in this study. The Ministry of Social Development (MoSD) is the line ministry responsible for senior citizens' issues (Government of Province-1, 2020). The state endeavors for the elderly care, by the center, province and local level in the federal republic of Nepal, needs to be explored. The state is expected to prepare and implement suitable policies and programs. There are constitutional provisions for special protection and social security for the senior citizens (article 18, 41 and 259 of the Constitution of Nepal, 2015). The fundamental rights for the senior citizens (article 41), have provisions for special protection and social security from the state. Management of the senior citizens comes under the list of the power and function of the local government (Number 16, Schedule 8 of the Constitution of Nepal, 2015). There are various acts, laws and by laws in the country along with the international instruments to which Nepal is a party. 'Honored, easy and happy ageing' is the vision of the government in province number 1 .

Article 4(1-5) of the Senior Citizens Act 2006, provides that

It shall be the duty of each family member to maintain and care the senior citizen to the level of the economic status and prestige of the members. Where a senior citizen has lived separately or wishes to live separately taking his or her partition share, the family member of his or her choice shall keep with him or her and maintain the senior citizen. No one shall detach the senior citizen from the family or compel the senior citizen to get detached from the family in violation of his or her will. Where the economic condition of the senior citizen of the family member maintaining the senior citizen is weak, other family members shall make provision of maintenance and care of the senior citizen in spite of the fact that such member has not kept such senior citizen with him or her. Notwithstanding anything contained elsewhere in this section, any family 
member, relative or heir who uses or deals with (consumes) the movable or immovable property of the senior citizen shall keep with him or her and maintain and care for such senior citizens.

Through the First Periodic Plan 2019-2024, the provincial government was found putting efforts in creating a safe and dignified environment ( $p$ : 71) for senior citizens in the province with two major strategies to convert the aged people's knowledge and skills into social capital, and safeguarding their fundamental rights along with their social security provisions. However, enough actions and policy instruments were to be developed for wider implications in creating a stronger base for senior citizen related policy generation, steering the future plans of actions and their effective implementation (KII, Nov 2020).

The population of Province No. 1 is 45, 34,943 which is 17.12 percent of the total population in Nepal. The population of age 60 years and above in this province is 384,285 (female; $190353 \&$ male; 193932) which is again 8.47 percent of the total population in the province (CBS, 2011). The Social Development Section (SDS) under the Ministry of Social Development (MoSD) was found having special focus on day care centers, inter-generational skill transfer, and establishment and management of an old age home. In line with the Senior Citizen Act 2007(2063BS), the MoSD has emphasis on all three categories of senior citizens; senior citizens, helpless senior citizens and incapable senior citizens. There were Civil Society Organizations (CBOs) at the community level that advocate for formulation and amendments in the existing family law, emphasize on awareness building, and promotion of dignity along with identification and categorization of the senior citizens based on their high, middle and low economic status. In the financial year 2018-19, the ministry allotted budget for the development of physical infrastructures of the day care centers and old age homes at 17 different locations in 8 different districts of the province (MoSD, May 2019). The Annual Development Program (2020-21) reported the progress of having provisioned with financial grants through the Ministry of Social Development to 35 day care centres and 6 old age home in the province.

A study conducted by the MoSD in Province No.1 on the 'Status of Management of Senior Citizens' in 2019 found that certain causes including urbanization and nuclear family styles, behind the family deprivation of the senior citizens are foreign migration of children for education and employment, job, business and daily occupied schedules, globalization and urbanization, misbehaves due to degradation in social values, having no kith and kin and caretakers for the senior citizens, the desire for an independent life, and personal nature of the senior citizens(MoSD,2020)and the provincial government had set a target to provide safe and dignified living status to 
$40 \%$ senior citizens in the fiscal year 2019-2020(Province Profile 2019). However, no further programs have been implemented in the province due to limited social mobility and budgetary constraints after the COVID-19 pandemic (KII, Jan 2021).

Family level elderly care was found more important than the state initiatives of old age homes for senior citizens and certain variables got importance in the conversation for the elderly population. Maiya (2017) provided important tips on socio-psychological health and wellbeing for the senior citizens and home care. The older population requires special attention and treatment. Importantly, there is a role reversal as parents look after their children; the children should look after the parents when they are old. Home safety measures and comfortable living are essential to avoid the home hazards for the elderly. The specific focus Maiya provided were to avoid uneven flooring, proper lighting, gadgets that elders can trip on. Regular physical exercise and nutritional supports were suggested as an important health tip for the elderly Balanced diet with enough carbohydrate, protein and vitamin D level are required for keeping the elderly bones straight. Two levels of healthcare were prescribed important; preventive level that the elderly do not acquire any ill health and at therapeutic level for hypertension, dementia and Parkinson disease. More importantly, medication and rapport with the elders and handling them well could give them a feeling that they are independent. Besides, their social activities and old age socialization, family members spending time with them at least at breakfast, lunch and dinner could help them feel wanted. Provision of enough space so that they could feel independent and feel that they were in a comfort zone could psychologically support the elderly Further, giving them financial independence so that they could decide investment and expenditure (Maiya 2017).

The Government in Province 1 had formed a feasibility study committee for the establishment of 'JyethNagarik Gram' (Senior Citizens' Home) for which the required land acquisition and Detailed Project Report (DPR) preparation had also been done. However, there were some basic issues of interest in this regard including the indicators of the old aged home, intergenerational knowledge sharing and classification of the senior citizens. Efforts were also made for formulation of provincial policy for the senior citizens. The Provincial Government gave away additional incentives of rupees five thousand each to 2770 senior citizens of age 90 and above from 46 different local palikas (KII, Jan 2021). However, there is a greater need for bringing about desired change with the involvement of private and public sector agencies with focus on ageing population. Life of the emigrants and the population left behind are of academic and policy concern in a context when the socio-cultural setting and standards of the Nepali society is that family support system is primary practice in the society, and the children (primarily the sons) are obliged caretakers of the elderly parents, and any 
variation to this practice is not perceived as normal. Family life is equally important in adding qualitative significance and dignity for the elderly parents.

\section{The Selected Narratives of the Elderly Parents}

The respondents, during the research interviews and FGDs were found unevenlyagreed that Nepali citizens can have active life even after their official retirement (58+years) age. However, there is a role of the family in keeping the older people active. The longevity of Nepali people has increased along with the pace of development in the country (progress in health care facilities, educational development, and access to comfort in daily life) and the consciousness about the safety of self and family. However, there could be individual perceptions of 'being old'which is a psychological issue in many. If someone decided (emotionally) to live for a hundred year, they can remain active for 80-85 years of age. The condition is, they shall not fall physically sick and they shall be able to take proper food. Attention and freedom are important for the elderly. A family shall create such an environment. However, the respondents in an FGD told that there were a considerable number of senior adults who are in very poor living status, some of them told that they were deprived of national policy protection, they did not get health and nutritional care were forced to enter into an 'older stage' (feeble and dependent stage) due to their physical condition.

The research respondents accentuated that a conducive environment for 'active $60+$ ' shall be created socially and culturally. This category of respondents expressed that there is, more or less, a socio-psychological perception about ageing in the society. There are some dull sayings in Nepali society such as JabaPugyoSaathi, HaatmaaLaathi (when at sixty, stick on hand) that reduce the valor in older people and bear a social stigma against the dynamism in life. A healthy lifestyle (with a good food habit; keeping away from junk food, no smoking and avoiding alcohol) and taking regular physical activity (exercise) are important equally.

The respondents opined that there are ways that elderly people can keep themselves busy. Even an ordinary Nepali woman culturally possesses various skills. Older women's skills of making duna-tapari (disposal natural leaf bowl and plates), battikaatne (cotton wick making) and many such others not only keep them engaged but also help in addressing the specific family needs and earn some income. The social activists and social organizations working for the senior citizens shall create more innovative ideas and enhance the required social awareness on this aspect. Senior citizen friendly families can be developed in the society. Cultural practices transmit from one generation to the next. Children learn the family behavior towards the senior 
citizens (grandparents) from their parents. Healthy old people with a decent mental capacity living in a conducive environment can manage comfortable second innings.

A group of civil society member expressed that being financially independent, emotionally strong and socially empowered are equally important for the aged people. Appropriate state policies for senior citizens shall be formulated; effectively implemented and timely revised. The state policy on retirement shall be revised. The retirement age in the country shall be 65 years. Retirement of public servants at a productive age is a national loss and policy fault.

Outmigration of the younger generation not only brought socio-economic changes and profoundly influences the customary family structure. Migration of children further impinges on the older people's socio-psychological expectation on their family life and their living conditions. The research respondents had their own perspectives for the question on who is more responsible; those who migrated abroad or the state policy that could not address the expectations of the young generation. Two out of the 15 respondents in an FGD at a day club in Biratnagar were found much vocal on telling that this is the failure of the present generation that forces the youths to migrate. "This is mainly because those in the government could not make appropriate policies; the government does not have appropriate vision. The state policy is unable to accommodate the young generation addressing their requirement of education, job assurance and social security of life. The government could not calculate their life requirements, which remained as the push factor for youths' migration". However, there could be several pull factors such as making more money and earning more comfort. The 'imagined society' of the youths was different from the one they avail in their home country. There could be several 'foreign factors' luring the youths.

The respondents were of the opinion that the young generation is more attracted to foreign lands. Nepal has adopted a faulty education system. There is an intergenerational attitude gap that comes along with the gaps in socialization and faulty curriculum education. English education is not necessarily the only option. 'Love for home', 'desh bhakti' and 'loyalty to parents' are missing in the education curriculum. We shall never expect that the migrated young generation return back home.

There were senior citizens who expected state protection. They believed that the social organizations working for senior citizens should provide support to the senior citizens care system. In fact, there needed a collective responsibility. There is a stage of ageing which is biologically factual and medically certified. During this role reverse stage the role of family to their older parents is primary. On the other hand the state does not have appropriate age specific approaches. Social protection provisions of contribution based social security could be very ideal. If there arrived someone, in the family, who could take care of the old age people, should be provided 
with the fund. But there were some categories of people who needed full support from the state. The management and delivery of health services for the elderly people was found important. WHO (2015) expressed concerns on the growing need for home health care for the elderly. This study report of WHO insisted on home health care for the elderly as an integral part of primary health care services in any member country.

Timely change in community behaviour was evenly emphasized. Ritual and cultural changes should be recognized timely. 'Virtual naming ritual of the newborn and rice feeding ceremony are becoming common these days' a 65 years old respondent, whose children are abroad and elderly parents at home are very familiar with the use of modern means of communication, told in an interview. In absence of sons, the daughters could be privileged for death rituals and even son in laws should have the privilege rights. The plan of senior citizens shall be going independent, be active as much as you can, educate the next generation. Public Private Partnership (PPP) model for the management of elderly parents shall get priority. The social institutions/organizations working for the elderly parents shall generate funds to address the needs of the elderly citizens. Government's commitment to implement the existing provisions related to social security of the elderly people is a primary need.

In a specific case study, a respondent who is an 86 year old single mother lives with several old age complications and her weaker health conditions due to high blood pressure, diabetes and uric acid. Her hearing capacity is getting lower. Her son is settled in the foreign land. The old lady wants her son to perform all the family rituals including the 'shradha' for his father. This sometimes creates inconsistencies on both the sides. The son wants his mother to decide to live with the family abroad but the old lady wants to spend her rest of life and to breathe her last in the home built by her husband. The son is equally aware that his old mother gets all the elderly care for which he is ready to make payments of any charges. But such facilities are not available in the town.

A couple with an 85 years old man and an 83 years old woman, live with one of their 5 married daughters, who was back to her parents at an early age after her marriage was unsuccessful. The old couple moved to Biratnagar, following their three sons, from the eastern hills where the family had good earnings from their commercial farming. But their three sons have migrated abroad. The couple is living an active and healthy daily life to date. They spend 4 hours per day in the local day care centers with other senior citizens. But are equally apprehensive about their remaining years of life and bother about their care if they are seriously ill and become unable for physical movement.

The challenges of the senior citizens were not necessarily financial or biological but also as issues of freedom and reason. A respondent who is at his 65 and a retired 
officer of GoN was found socially very active. Works as a private auditor and feels economically independent. The respondent is living happily with his 61 years old wife and both of them feel financially secured. He had two 2 sons and both of them migrated to a developed country with their family. They were sent by the parents themselves. The one elder one has taken the Japanese citizenship and the younger is there on a working visa. Higher education and better opportunities pulled the youths for migration; however they preferred to reside there permanently. Both of the parents are healthy and do not need regular medical care. They do not miss their sons at this period of time, however the mother insists that their younger son shall return home with his family in 10 years time. The argument of the mother is that, after their 70 s the old couple will need someone to support them. Further, her son and daughter- in-law are well educated, will get a better job in their home country and their children can continue their education in their home country.

Responding to the research questions on old age issues, a 72 years old respondent pointed out some policy drawbacks in the country. The respondent argues that the young generation shall not be encouraged to migrate for the sake of remittance. The government shall create local employment opportunities to encourage the youths to stay in the country. This will further bring back the beauty of family life: living with family gives value for elderly parents. Thus the national policy issue is very important. Enough job opportunities shall be created in the country.

\section{Conclusion}

The number of elderly people is gradually increasing in Nepali society. Family members used to be the primary caretakers of the elderly parents in this society. The older parents still prefer family life with their children and separation is not a choice for them. But the loneliness of the childless and left behind parents of the migrated children has become a major psycho-social issue in contemporary society. The financial status of the lonely parents plays a decisive role in their second innings life maintenance, but their age is a major factor in determining the challenges for everyday life and simply financial wellbeing is not enough for them. It's also equally true that older parents require social security from the state when they and their families are not sound financially. However the older parents prefer the love and care from their own children. Conditions of old age sickness and illness are of primary concern in the family life. Family rituals also matter extensively. However, a significant number of the respondents laid emphasis on the state responsibility to older citizens. Specially, those who do not have children with them shall get state protection. The sociopsychological attitudes on family functions and male dominated roles are changing and shall be apprehended by the society. Children who had migrated to developed countries for higher studies prefer to stay over there. The children say 'We are happier 
here'. Old age life becomes troublesome for the elderly and it needs someone to take care. No parents discarded their children, whatever their status was. The old age home gave some of them a new identity and a new family. But sending the elderly to an old age home was not the ideal solution. The provincial government was found making several efforts on issues on care for the senior citizens. But those efforts still lacked in enough policy instruments and there were certain gaps in the present guidelines and with the reality of the implication. Further, rather than developing a blanket approach, a strategy of a 'maayaalu pariwar, samaweshi samaj ra sahayogi sarkar' (lovelier family, inclusive society and supportive government) stayed strong behind the expectation of the respondents. This research finds scope for further research and also expects to provide a stronger base for guiding the future plans of works of the provincial and local governments.

\section{References}

Agrawal, A., Lubet, A. \& Mitgang, E. (2020) Population Ageing in India: Facts, Issues, and Optionshttps://www.academia.edu/31607300/Population_Aging_ in_India_Facts_Issues_and_Options

Annual Development Program (2020-21) Province Planning Commission, Province -1, Nepal

Constitution of Nepal (2015)www.lawcommission.gov.np/en/archives/979 First Periodic Plan (2019/20-2024/25) Province Planning Commission, Province -1, Nepal

Gautam, T. (2008). Migration and the Problem of Old Age People in Nepal. Dhaulagiri Journal of Sociology Journal of Sociology and Anthropology https://www. nepjol.info/index.php/DSAJ/article/view/1361

Geriatric Center Nepal (2010). Status Report on the Elderly People (60+) in Nepal on Health, Nutrition and Social Status Focusing on Research Needs: A Report Prepared for the Government of Nepal, Ministry of Health and Population, Ramshahpath, Kathmandu. https://www.academia.edu/39059183

Government of Province-1.(2020). Mid Term Evaluation 2020. The Office of the

Chief Minister and Council of Ministers \& Province Planning Commission, Province -1

Joshi, M. (2019). Living Arrangements and Quality of Life of Nepalese Elderly in Rural

Nepal. Indian Journal of gerontology. https://www.academia.edu/41469006/

Parker, S. Nikku, B.R. \& Khatri,R. (2014). Social Policy, social work and age care in Nepal: Mapping Services and missing links. European Journal of Social Work. https://www.researchgate.net/publication/263286718 
Province Profile (2019-2020). Province Planning Commission, Province-1, Biratnagar, Nepal

Maiya (2017).Easy Tips for Taking Care of Elderly Parents.Portea Medical Health https://www.youtube.com/watch?v=eZFFGQHienY

MoSD, (May 2019).http://mosd.p1.gov.np/sites/mosd/files/2019-05/pdfSeniorCitizen Act of Nepal, (2006).http://www.lawcommission.gov.np/en/archives/19011

Shrestha, L. (2012). Geriatric Health in Nepal: Concerns and experience. A review article,https://www.nmcth.edu/images/gallery/Review\%20 Article/oVWgaL\%20Shrestha.pdf

Ossewaarde, M. (2014).Sociological Imagination for the aged Society. Canadian Journal of Sociology(Vol.39,Issue2https://journals.library.ualberta.ca/cjs/index. php/CJS/article/view/22247

UNO.(2002). Political Declaration and the Madrid International Plan of Action on Ageing, Second World Assembly on Ageing, Madrid, Spain, 8-12 April, 2020. https://www.un.org/en/events/pastevents/pdfs/Madrid_plan.pdf on 11 July 2020

UNO(1991). United Nations Principles for Older Persons. Adopted by General Assembly resolution46/91of16December1991.thttps://www.ohchr. org/en/professionalinterest/pages/olderpersons.aspx

UNO. (1998).Macao Declaration on Ageing for Asia and the Pacific, 1998. http://www. monitoringris.org/documents/norm_reg/unescap-macao.pdf, UNO (2000) Guidelines on the implementation of the Macao Plan of Action on Ageing for Asia and the Pacific. https://digitallibrary.un.org/record/469308? $\ln =$ en

UNO. (2018). Ageing Related Policies and Priorities in the Implementation of the 2030 Agenda for Sustainable Development - As reported in the Voluntary National Reviews of2016,2017and2018.https://www. org/development/desa/ageing/wpcontent/uploads/sites/24/2019/07/AnalysisAgeing_VNRs_Final28122018.pdf

Upadhyay, C. (2020).Nepali Speaking Populace in India: A Brief Review of the Historical Context and Current Discourse, in Rahul Mahant (edt) A Collage of Indian History, Rudra Publishers \& Distributors, pp. 124-149

WHO. (2015). The growing need for home health care for the elderly as an integral part of primary health care services. World Health Organization https://applications. emro.who.int/dsaf/EMROPUB_2015_EN_1901.pdf?ua=1 


\section{Author Note}

This paper is primarily based on my interest in listening and analyzing the narratives of the elderly Nepali parents with an informal engagement of volunteer social advocacy, for more than five years, in locally supporting issues of ageing population. Recently, an opportunity of working as an expert for the concerned department of Social Development Ministry in Biratnagar of Province -1further encouraged me for a research in this area. However, I have no conflict of interest to disclose in this independent research work. I am grateful to all the elderly parents for their responses, and the subject experts for their review and comments in finalizing this paper.

*The phrase 'situation of the elderly' is multi-dimension with several possible variables to study in each dimension. There are broad spectrums of issues related to the senior citizens in terms of their social, economic, health, nutrition, psychology, and overall well being. The age of the migrants and the age of the left behinds, the economic status of the family (higher, middle or lower), the place (rural or urban) from where the migration takes place, the occupation of the migrant family (agriculture, service or business), caste and ethnicity of the population affected by the migration, and several other factors are to be considered while examining the effects of migration and physical absence of children on the left behind parents. However, this study keeps a limited scope while studying the selected elderly parents' perceptions on their care at home.

${ }^{\wedge}$ As per the Senior Citizen Act 2006 (article 2,a), a senior citizen is a citizen of Nepal having the age of sixty years. 